ORAL-POSTER

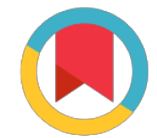

Check for updates
*For correspondence:

sophie.tranthi@gmail.com

Competing interests: The authors declare that no competing interests exist.

Received: 2017-03-30

Accepted: 2017-06-25

Published: $2017-09-05$

Copyright The Author(s) 2017. This article is published with open access by BioMedPress (BMP).

This article is distributed under the terms of the Creative Commons Attribution License (CC-BY 4.0) which permits any use, distribution, and reproduction in any medium, provided the original author(s) and the source are credited.

\section{In vitro selection of macrocyclic peptides against THG-1 for Esophagus Squamous Cell Carcinomas therapeutic lead compounds}

\author{
Dung T.Phuong Tran ${ }^{1}$, Hiroyuki Suzuki ${ }^{2}$, Christopher J Hipolito ${ }^{3}$ and Mitsuyasu \\ Kato $^{2}$
}

\section{Abstract}

Ineffective current treatments for esophagus squamous cell carcinoma (ESCC) is one of the main reasons for its low 5-year survival (20\%). Transforming growth factor beta-1 stimulated clone 22 - isoform 4 (Tsc22D4/THG-1) is overexpressed in $92.6 \%$ of ESCC specimens while strictly resided in mitotically active basal layer of normal squamous epithelial tissue. Knockout of THG-1 caused reduction in cancer cells growth, invasion and tumorigenesis. Experimentally, protein-protein interactions (PPIs) were identified as THG-1 mechanism to promote cancer progression. Wellknown cellular regulators', Keap1, $\mathrm{PHD} 2, \mathrm{TBLR} 1$ and $\mathrm{NRBP}_{1}$, functional interactions are disrupted in the present of THG-1. To develop THG-1 PPIs antagonist, Random non-standard Peptide Integrated Discovery (RaPID) system was employed. In this system, D-stereochemistry, unusual side chains and $\mathrm{N}$ - methylation containing macrocyclic peptides was generated and screened against THG-1. High-specificity, flat-surface binding ability, rigidity make those peptides to be more advantageous for PPIs blocking compare to small molecules and antibodies. Herein, I discuss the process to identify potential lead compounds for ESCC therapeutic by blocking THG-1 PPIs.

\section{Keywords}

Esophagus, squamous carcinoma, macrocyclic peptide, RaPID system, therapeutic, THG-1, Keap1, PHD2, TBLR1

\section{Funding}

\section{References}

